\title{
Analysis of vegetation from satelite images correlated to the bird species presence and the state of health of the ecosystems of Bucharest during the period from 1991 to 2006
}

\author{
Mirela Dragoș ${ }^{\mathrm{A}}$, Angela Petrescu ${ }^{\mathrm{B}}$, George-Laurențiu Merciu ${ }^{\mathrm{C}}$ \\ Received: January 1, 2017 | Revised: January 30, 2017 | Accepted: March 18, 2017
}

DOI: $10.18421 / G P 21.01-02$

\begin{abstract}
The urban vegetation needs adequate monitoring and conservation, being a critical resource of urban landscape. To its deeply esthetic values, the practical values and, respectively, ecosystem services delivered by the urban biodiversity are added (amelioration of the environment and urban microclimate, flood control, diminishing of the environmental pollution, increasing of biodiversity and habitats etc.). Accurate remote sensing techniques have been used widely in locating and mapping urban vegetation (Light Detection And Ranging-LiDAR, satellite images).

The purpose of this study is to point out the vegetation status in correlation with the number of the bird species (as indicator of the ecosystem's health), using remote sensing techniques (Landsat satellite images), between 1991-2006 in Bucharest, Romania's capital. Rapid urban evolution of Bucharest led to important changes within the structure of the city, underlined by the increasing of the built area to the detriment of the green one. The intensity of the urbanization rate also led to the decreasing of the number of the bird species. The results obtained through analysis of satellite images indicate the necessity to acquire the up-to-date information related to the vegetation status in order to establish in the future, through urban landscape projects, protection measures for the vegetation cover and for the bird habitats in Bucharest Municipality.
\end{abstract}

Keywords: urbanisation, vegetation monitoring, avian habitat, Landsat, NDVI model, Bucharest Municipality

\section{Introduction}

Urban agglomerations modified and modify continuously the environment, mostly generating beneficial effects for inhabitants' life and activities, and, at the same time, negative effects, both on the environment structure and social-economical life.

The results of the studies of the last 20 years support the approach and inclusion of the ecosystemic di- mension in the integrated urban regeneration of the cities. Green areas represent an important resource of the urban system and, implicitly, a tool which helps to better manage the urban development (Colusca, Alpopi, 2011; Feltynowski, 2015; Nita, 2016; Antrop, 2004 quoted by Scaunas, Merciu, 2016; Ianos, et al., 2017).

Green infrastructure is a new concept, a net projected within cities, in which there are incorporated

\footnotetext{
A University of Bucharest, Faculty of Geography, Doctoral School "Simion Mehedinti - nature and sustainable development", N.Bălcescu Blv., 1, 010074, Sector 1, Bucharest, Romania; mir.dragos25@gmail.com

B "Grigore Antipa" National Museum of Natural History, 1 Șos. Kiseleff, 011341 Bucharest 1, Romania

C University of Bucharest, Faculty of Geography, Department of Geomorphology, Pedology, Geomatics.

N.Bălcescu Blv., 1, 010074, Sector 1, Bucharest, Romania; george.merciu@geo.unibuc.ro
} 
natural and semi-natural elements as woods, public parks, recreational areas, waste vegetation, resendential gardens, street alignments of trees and bushes, vegetal strips, green belts (Feltynowski, 2015; Nita, 2016; Rouse, Bunster-Ossa, 2013; Ely, Pitman, 2013), and recently, green walls and grassy terraces (Maas, et al. 2006; Hopkins, Goodwin, 2011, Cheng, et al., 2010, Dunnett, Kingsbury, 2004; Rayner, et al., 2010).

Green areas deliver a series of natural functions, often named ecosystemic services, including the air and water purification, healthier soils, improvement of the urban climate and microclimate (Millennium Ecosystem Assessment, 2003; Wolch, et al., 2014; Nita, 2016), playing an important role in water infiltration in the ground and in the restoration of aquifers (Xiao, et al. 2006; Bartens, et al., 2008), water interception at the tree canopy level (Xiao, et al., 2006), as well as the flooding control (Lull, Sopper 1969; Craul, 1992; Chen, et al., 2006 quoted by Wolch, et al., 2014), diminishing the environment pollution by capturing the dust particles (Nowak, et al., 2006; Mitchell, et al., 2010; Dogon-Yaro, et al., 2016), increase of biodiversity and habitats (Lima, et al., 2013; Petrisor, 2015; Hüse, et al., 2016), low noise (Fang, Ling, 2003; Van Renterghem, et al., 2012; Wolch, et al., 2014).

A valuable benefit of the green infrastructure is represented by the diminishing of the heat island effects (Bornstein, 1968; Federer, 1976; Rosenfeld, et al., 1998; Wolch, et al., 2014; Sirodoev, et al., 2015; Davis, et al., 2016; Ongoma, et al., 2016).

Also vegetation provides nesting sites for birds and provides support to a number of insects, which, in their turn, are a food source for birds and other wild species. Trees and shrubs that produce fruits and seeds are a direct food source for many bird species. In urban settings, linear corridors between different types of habitats are among the most important, creating the connection between different isolated areas, and between towns and adjacent rural environment.

The role of the green infrastructure is major in generating social and economical beneficial effects: provision of green spaces and recreational facilities for residents, improving of the population health, pleasant design in residential areas and a better rating of real estate, etc. (Alberti, Marzluff, 2004; Conway, et al., 2010; Colusca, Alpopi, 2011; Cohen, et al., 2012; Wolch, et al., 2014; Feltynowski, 2015; Lee, et al., 2015; Davis, 2016; Li, Liu, 2016).

This study intends to make a prior analysis of the urban green areas from the perspective of their recovery. Within the study, the authors captured the evolution of Bucharest municipality in the terms of built area - green area ratio, between 1991-2006, in correlation with the state of health of vegetation and with the state of environment (the birds being chosen as a quality indicator of the environment).
Bucharest knew an accelerated urban evolution beginning with the second half of the 19th century (Mihailescu, 2003 quoted by Ianos, et al., 2014) which still continues. Along time, as the city enlarged, natural vegetation diminished in some areas as a result of the building and adjacent infrastructure construction, in the detriment of the species unable to adapt to the new type of habitat. Biodiversity loss as a consequence of urbanization is worrying, because the decreasing of the number of species in an ecosystem points to a low ecological health and a poor quality of habitats.

In this respect, it is necessary the correct and rapid acquisition of the information on the state and changes of the structure of the urban vegetation, to subsequently be used as a tool in the decision process related to the improving of the urban ecosystem status. Urban landscape projects involve mostly the knowledge of the components of the urban space and their interconnections.

\section{Methods and data}

Accurate remote sensing techniques have been widely used in locating and mapping urban vegetation: Light Detection And Ranging - LiDAR (Holmgren, et al., 2008; Kim, Muller, 2011; Bellakaou, et al, 2016; Dogon-Yaro, et al., 2016; Näsi, et al., 2016; Scaunas, Merciu, 2016), satellite imagery (Bino, et al., 2008; Mcfarland, et al., 2012; Mészáros, et al., 2014; Jovanović, et al., 2015; Agrawal, et al., 2016; Burchfield, et al., 2016; Milanović, et al., 2016).

Remote sensing techniques present several advantages: speed of the measurements, efficiency, high resolution of the recording, acquisition of an important number of data in a digital archive, integration of all information from a certain area, an important tool for monitoring environmental conditions facilitating investigation and intervention, $3 \mathrm{D}$ images of a certain area, the support of collecting a set of relevant data and their integration into an easily accessible system for public use, and environmental control and management (Mcfarland, et al., 2012; Jovanović, et al., 2015; Milanović, et al., 2016).

For this study the authors used data obtained from the analysis of satellite images. Therefore, two satellite scenes were used: Landsat Surface Reflectance 4-5 TM at a resolution of $30 \mathrm{~m}$ (Table 1 ), from the $31^{\text {st }}$ of July 1991 and, respectively, the $17^{\text {th }}$ of August 2006.

Vegetation can be detected on the satellite images by its specific appearance and shades.

Vegetation analysis was performed based on cover infrared images that were created in the near and medium infrared spectral zone. Thus, in images acquired near-infrared spectral channel, vegetation appears in shades of bright red, while infrared images obtained in the medium infrared channel, the vegetation is detected by shades of dark red. 
Table 1. Spectral bands Lansat Thematic Mapper (TM)

\begin{tabular}{|l|l|c|c|}
\hline Landsat & Name & $\begin{array}{c}\text { Wavelength } \\
\text { (micrometers) }\end{array}$ & $\begin{array}{c}\text { Resolution } \\
\text { (meters) }\end{array}$ \\
\hline Band 1 & Blue & $0.45-0.515$ & 30 \\
\hline Band 2 & Green & $0.525-0.605$ & 30 \\
\hline Band 3 & Red & $0.63-0.69$ & 30 \\
\hline Band 4 & Near Infrared & $0.75-0.90$ & 30 \\
\hline Band 5 & Shortwave IR-1 & $1.55-1.75$ & 30 \\
\hline Band 6 & Thermal R & $10.40-12.50$ & $120^{*}(30)$ \\
\hline Band 7 & Shortwave IR-2 & $2.08-2.35$ & 30 \\
\hline
\end{tabular}

Source: Internet 1

The data obtained by satellite images can be processed through especially designed software applications, whose main role is to interpret remote-sensed images photographically. The authors used ENVI 5.1 program in order to analize the satellite images and presumed: creating vector file (polygon for resample) for Bucharest, clipping a raster for 1991 and 2006, creating multispectral images (Layer Stacking) and combinating bands for viewing.

The subsequent step was the extraction of the spectral signature from definite regions of interest (ROI), in ENVI program.

Also, the Normalized Difference Vegetation Index (NDVI) was calculated as a ratio between the difference and the sum between the infrared and red reflectance areas of the electromagnetic radiation (Mcfarland et al., 2012; Jovanović et al., 2015; Burchfield et al., 2016):

\section{$\mathrm{NDVI}=(\mathrm{NIR}-\mathrm{R}) /(\mathrm{NIR}+\mathrm{R})$}

where:

NIR - near infrared spectral band; $\mathrm{R}$ - red spectral band.
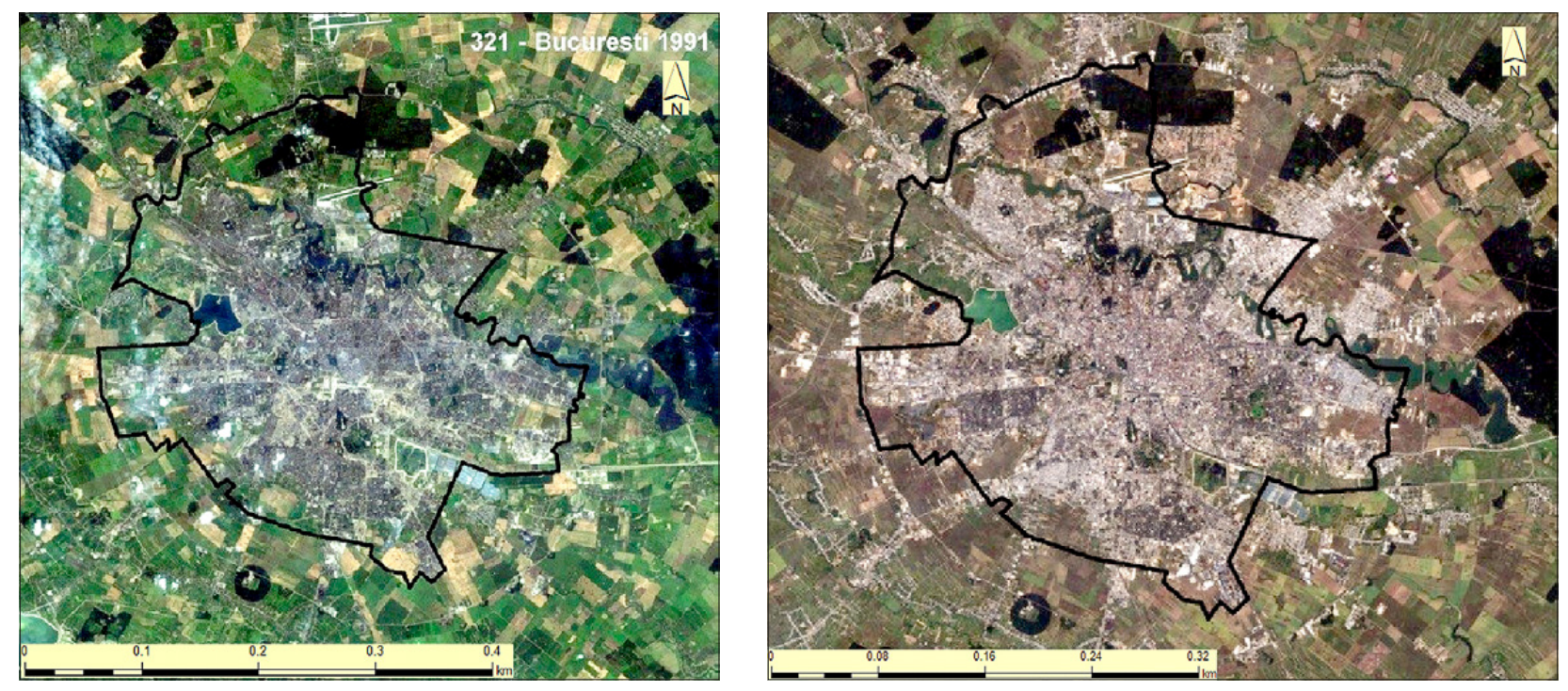

Figures 1 and 2. Combination of 321 of spectral bands for Bucharest (1991 and 2006) 

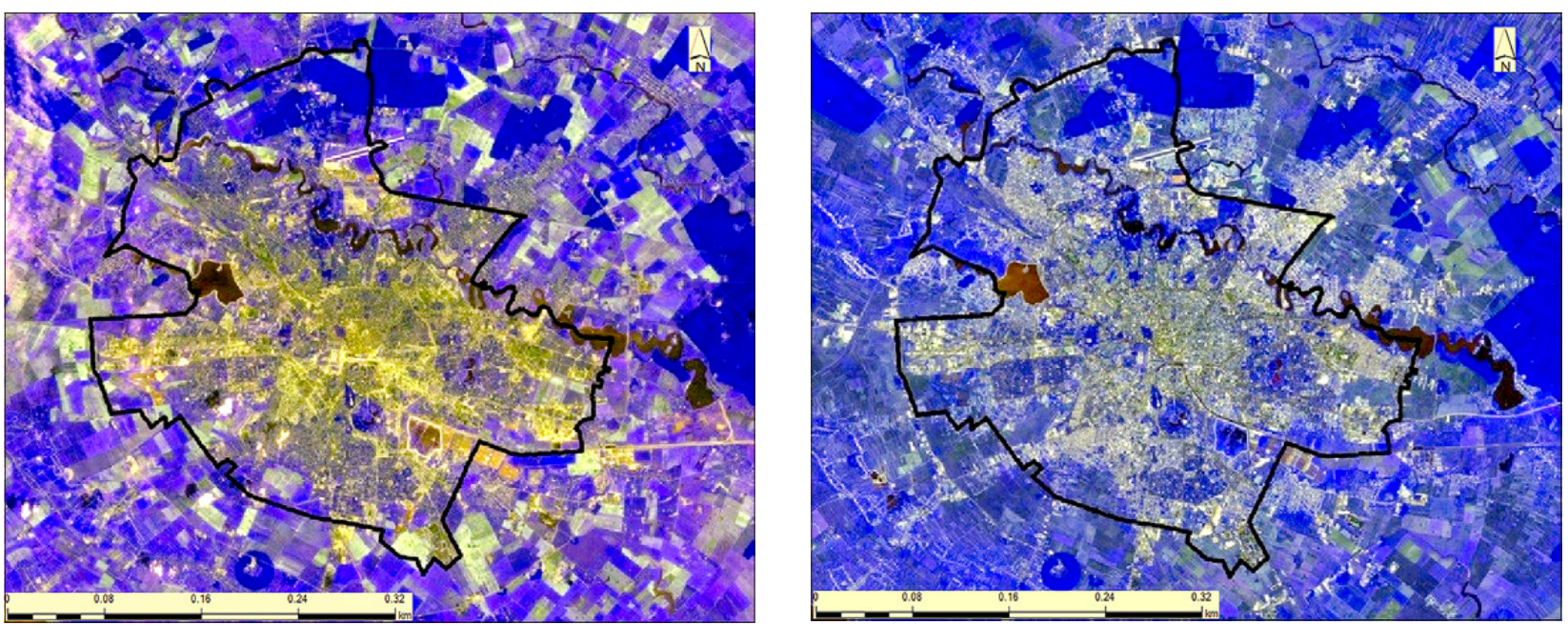

Figures 3 and 4. Combinations of 234 spectral bands for Bucharest (1991 and 2006)

er share of the agricultural lands was added, later, in 2006, it was observed the increasing of the building covered surfaces (with a higher dynamics in the suburban area of Bucharest, but also inside the city, especially in north-west and north-east areas), this fact leading directly to a diminishing of the green areas (Figures 1 and 2).

The image analysis related to the combination 234 was facilitated by the fact that it is the first to include an infrared band, thus permitting a clearer differentiation between building covered areas (built surfaces) and those covered by vegetation (Figures 3 and 4).

Combination 432 highlights the vegetation in red, lighter spots representing a stronger spectral response. Band 4 (NIR - near infrared) allows the differentiation between the vegetation types: forests are dark red, deciduous trees are represented by a lighter red, the agricultural areas and the grassy ones are very light red coloured (Figures 5 and 6).

An attentive analysis of the shades of red underlines better the changes of the city structure, i. e. the

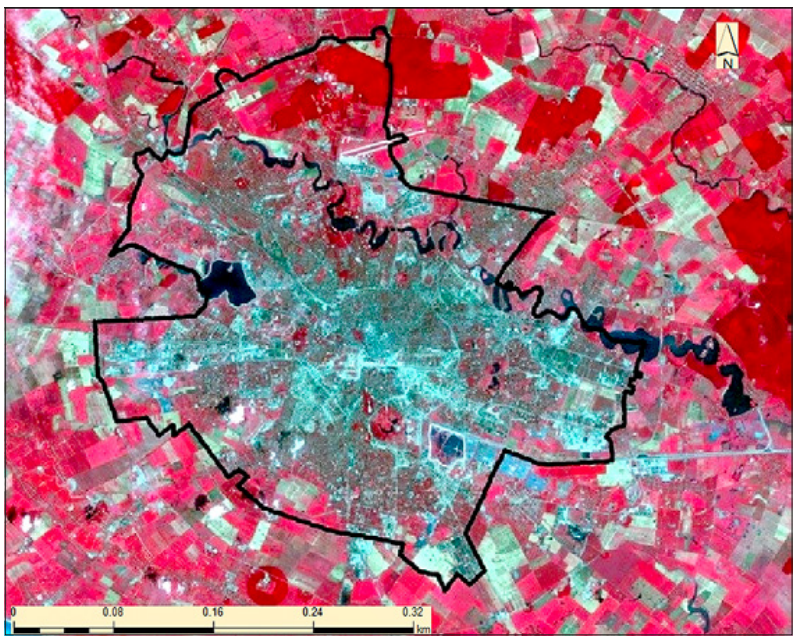

diminishing of the afforested surface beginning with 2006, in comparison with 1991, especially in the north of Bucharest.

From the interpretation of the satellite images related to combination 453 it can be observed that it is optimal for vegetation differentiation, due to the presence of two bands of the infrared (4 and 5) (Figures 7 and 8). The bands cause more pronounced shades of vegetation. Band 5 (shortwave infrared) is sensitive to changes of water content of the leaves or soil. Vegetation is represented in shades of orange and brown, lighter tints showing a stronger spectral response of the vegetation and the darker ones, a weaker response. The areas without vegetation and the built-up spaces, typical to urban areas, appear in shades of blue and gray (Figures 7 and 8).

Further, regions of interest (ROI) for water, constructions, grass, forest, park-deciduous, crops were defined, and later, the pixels were classified using Maximum Likelihood algorithm, with ENVI program (Figures 9 and 10).

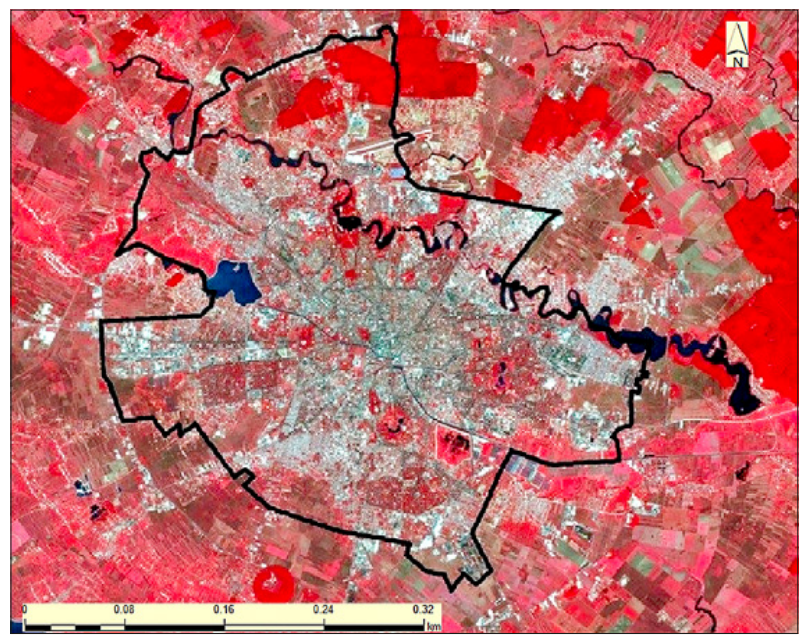

Figures 5 and 6. Combinations of 432 spectral bands for Bucharest (1991 and 2006) 

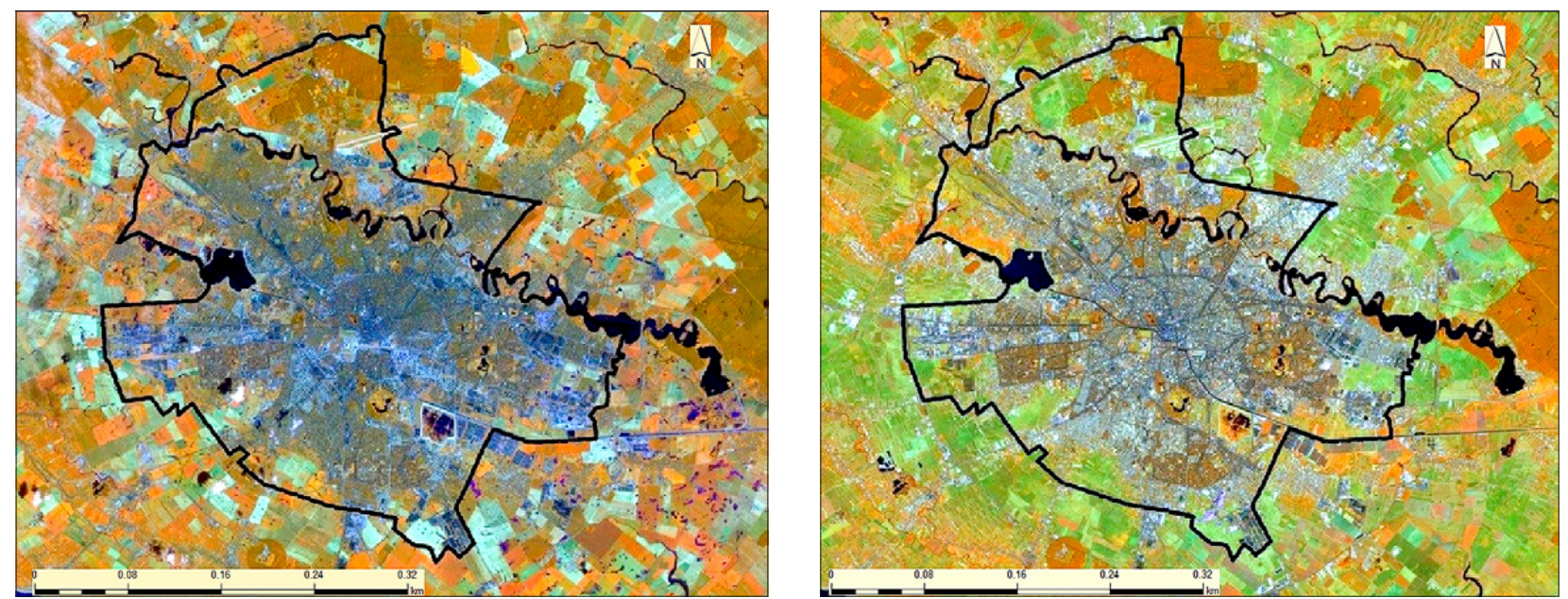

Figures 7 and 8. Combinations of spectral bands 453 for Bucharest (1991 and 2006)

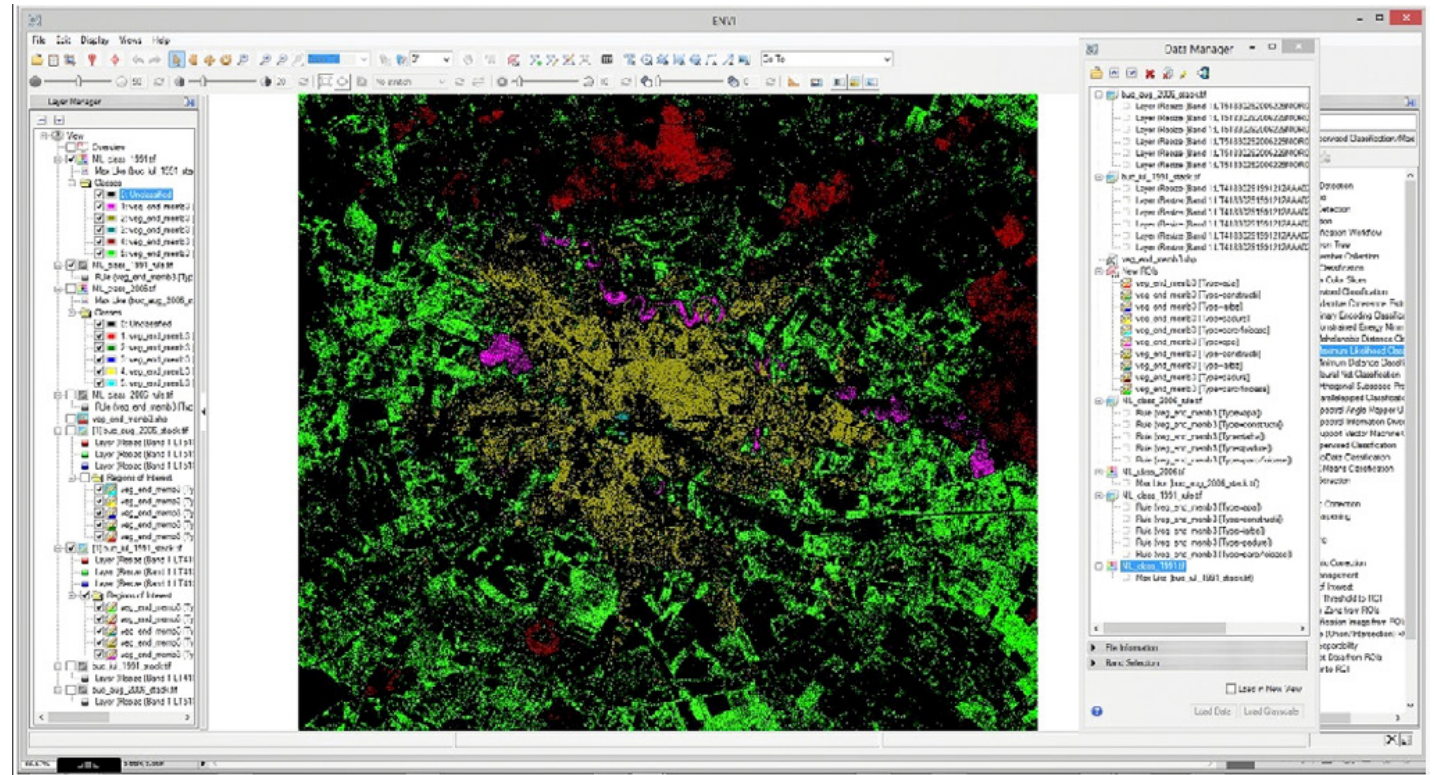

Figure 9. Screenshot of ENVI program during Maximum Likelihood Classification analyses for Bucharest, in 1991

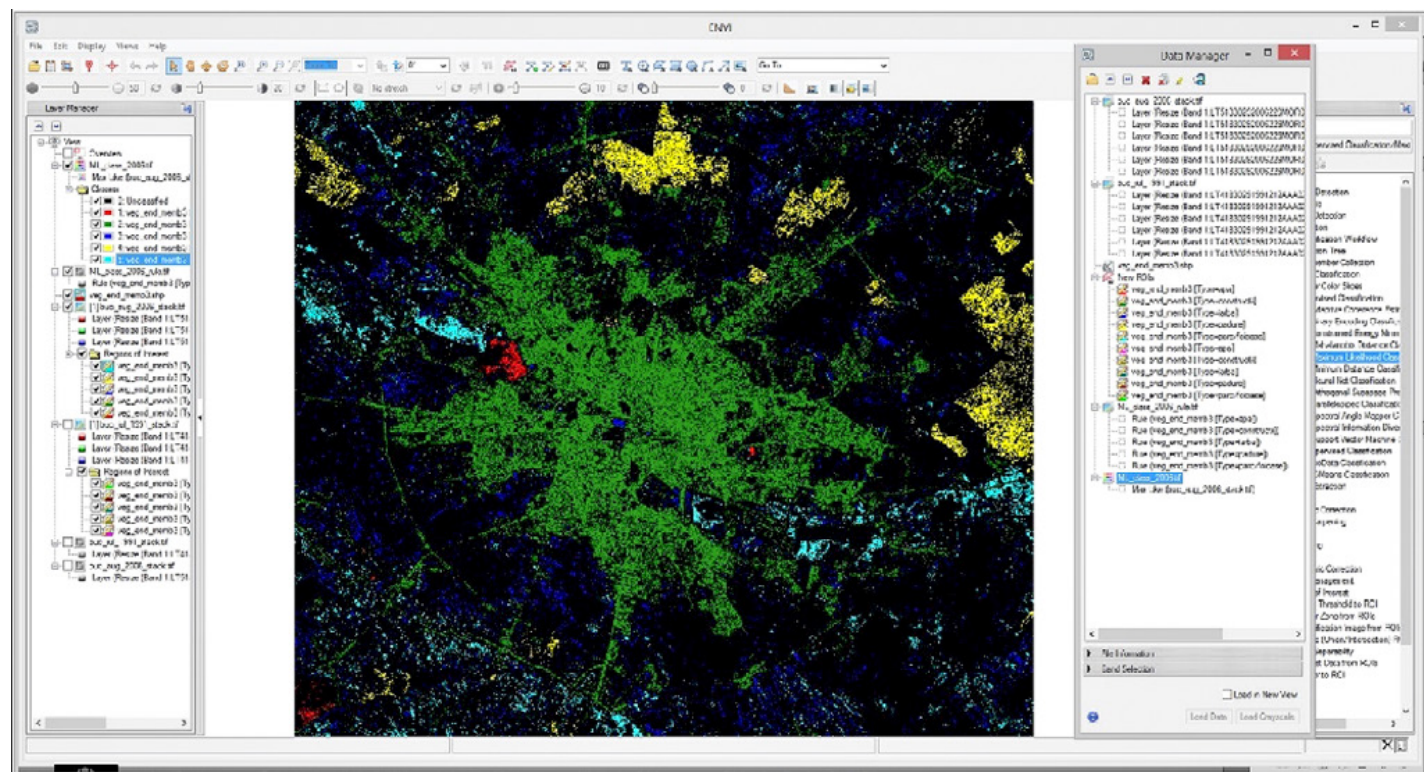

Figure 10. Screenshot of ENVI program during Maximum Likelihood Classification analyses for Bucharest, in 2006 

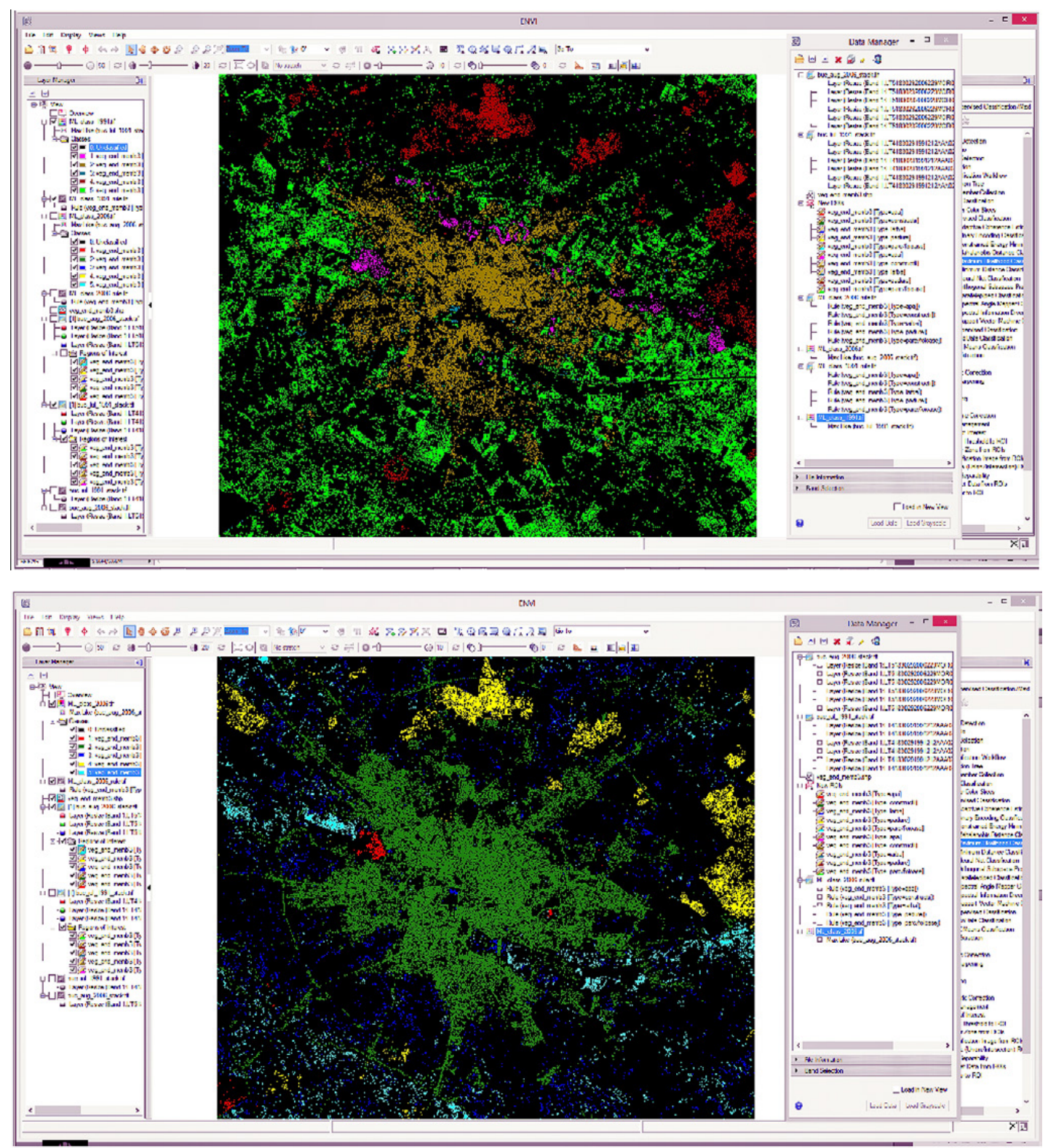

Figures 11 and 12. Maps exported from ArcMap on the classification of pixels in Maximum Likelihood Classification for Bucharest, in 1991 and 2006

Results were imported in ArcMap, with which the maps of the pixels classified for 1991 and 2006 were made (Figures 11 and 12).

Between 1991 and 2006 the built surface of the city considerably increased, emphasizing at the same time a drastic reduction of the green surfaces, and, as we shall see later, a decrease in the health of vegetation, correlated with urban biodiversity loss, especially of birds.

The two maps of the analysis of the vegetation health state were made in ArcMap, by the calculation of the Normalized Differentiation Vegetation Index (NDVI).

Sanogena vegetation, with a greater amount of chlorophyll, absorbs most of the amount of red light it receives, and instead reflects a large part of the near infrared radiation. Dry or rarefied vegetation reflects more of the received red light and less of the infrared radiation.

NDVI values vary depending on the absorption of the radiation by chlorophyll in red spectral area and its reflectance in the near infrared spectrum, and range between -1 and 1 , expressing the green vegetation consistency (Mihai, 2007, 2009, 2013).

The NDVI, which is an index of plant greenness or photosynthetic activity, has been used to distinguished pixels which belong to vegetation features on the digital image from those of other features. The output of this work is a new image file with NDVI values ranging from -0.3 to 0.9 (Figures 13 and 14). Values close to +1 (light tones) represent a thick consistency of vegetation and are specific to the dense deciduous forests. Values 


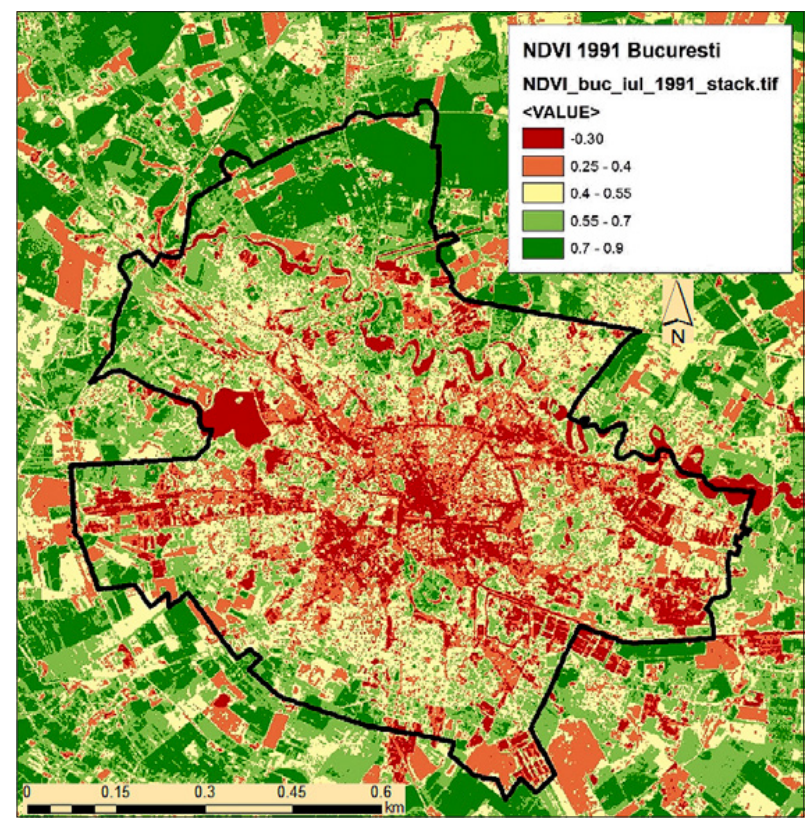

Figure 13. Map exported from ArcMAp as a result of the calculation of the Normalized Differentiation Vegetation Index - NDVI, in 1991

close to - 1 (dark tones) represent the land devoid of vegetation. Values close to o (intermediate tones) are associated to the land with grass or crops.

As it can be observed in the analysis of the Figures 13 and 14, in 2006, compared to 1991, green areas decreased considerably, both the public use and private, being replaced by buildings (NDVI values of -30).

Street plantations of the urban green area category of general use, which normally contribute by their presence to "the binding" of the green area system of a city, were broken and diminished, many of them disappearing. Small sized green areas were replaced by buildings, and the new residential complexes were built without green areas. Perimeter plantations of the public institutions (hospitals, schools, kindergartens, factories, etc.), which protected them from neighborhoods and traffic arteries, diminished or disappeared. In addition, the existing plant vigor, as we see in Figure 14, linked to the quality of chlorophyll spectral response is greatly diminished, degraded because of maintenance deficiency, water stress, acid rain and various diseases affecting the quality of vegetation (NDVI values ranging between 0.25 and 0.55 ).

As we will see further, these radical transformation of the urban structure, within a period of only 15 years, had also major consequences at the level of the city biocenoses.

Data from the analysis of satellite images were correlated with the presence of bird species on the territory of Bucharest, in 1991 and 2006 (Papadopol, Petrescu, 1991, 2006).

Bucharest is the host of an impressive number of birds observed along a year. Avian community of the

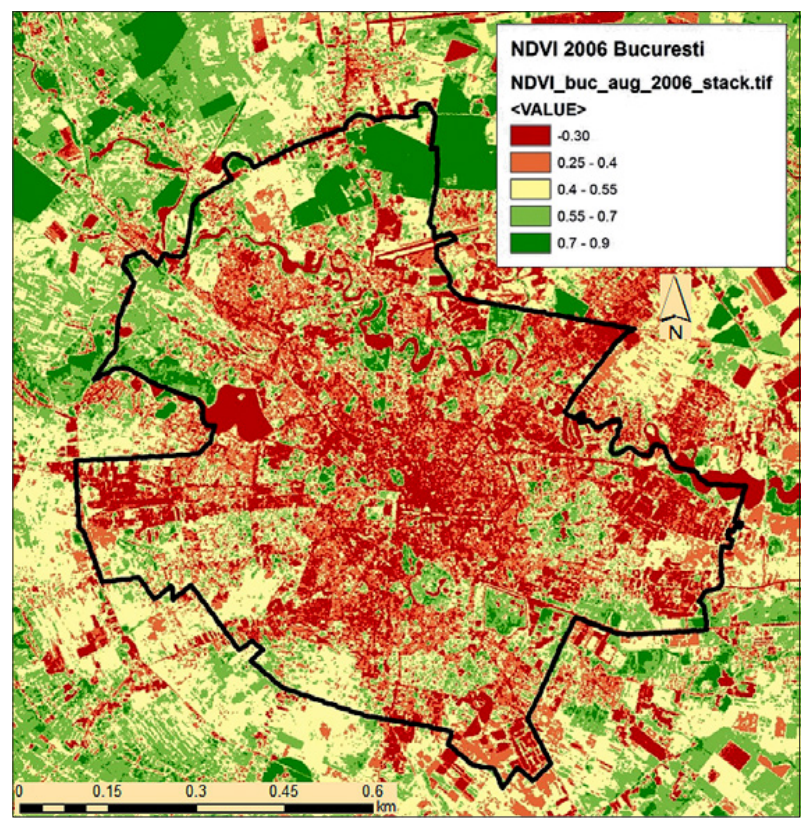

Figure 14. Map exported from ArcMAp as a result of the calculation of the Normalized Differentiation Vegetation Index - NDVI, in 2006

Bucharest city is made taxonomically of 135 bird species belonging to 19 orders, 44 families, 90 genera. The most numerous are Paseriformes, with 68 species (Table 2).

In the biocenoses where birds are included, and such kind of biocenoses are the most numerous, birds belong to different degrees of consumers, most of them having an important part in the general dynamics of the ecosystems, in the relationships and interactions between the biocenotic factors (Papadopol, Petrescu, 2006). Trophic relationships are the most important link between the species of a biocoenosis; every species becomes a link in the transfer and transformation of the substances and energy into biocenoses and ecosystem (Botnariuc, Vădineanu, 1982).

For Europeans, wild birds, most of them migratory, represent an extraordinary natural and cultural inheritance. Our continent is the home of over 530 species which can be observed along the year, with a total estimated population for over two billion pairs. Millions of them migrate to Africa, and others reach here, from the Arctic region or from Russia, during winter.

EU Biodiversity Strategy aims to achieve the objective of halting the loss of biodiversity, of the degradation of the ecosystem services and restoring them as quickly as possible by 2020 , and as a major objective, increasing of flocks (BirdLife International, 2015). Therefore, the Birds Directive was a major part of the EU legislative framework on Biodiversity Conservation.

In Romania, the status of protection of the bird species of community interest (SOR, 2015) under the aegis of: Directive 2009/147/EC, Emergency Ordinance no. 57 of 20 June 2007, the Red Book of verte- 
brates in Romania, Law 407/2006, Red List of Threatened Species IUCN 2012 - LR IUCN cat. 2012, Berne Convention 1979, Bonn Convention 1979, Agreement AEWA, Convention CITES (SOR, 2015).

According to specialized studies, the birds were classified in two large groups, one on species fenology and the other one related to the habitats where they were observed (Papadopol, Petrescu, 1991, 2006; Mohamad et al., 2013; Idilfitri et al., 2014; Morante-Filho et al., 2015) (Table 2, Figures 15 and 16).

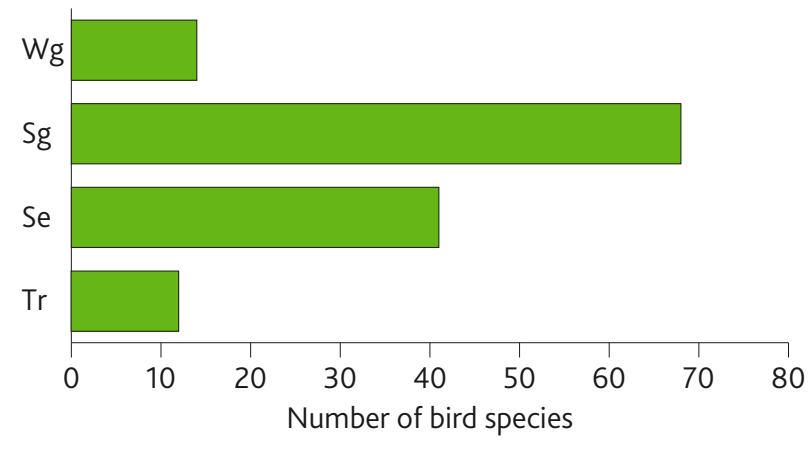

Figure 15. Species classification of the avian community after fenology ( $\mathrm{Wg}=$ winter guest, $\mathrm{Sg}=$ summer guest, $\mathrm{Tr}=$ transit bird, $\mathrm{Se}=$ sedentary bird)

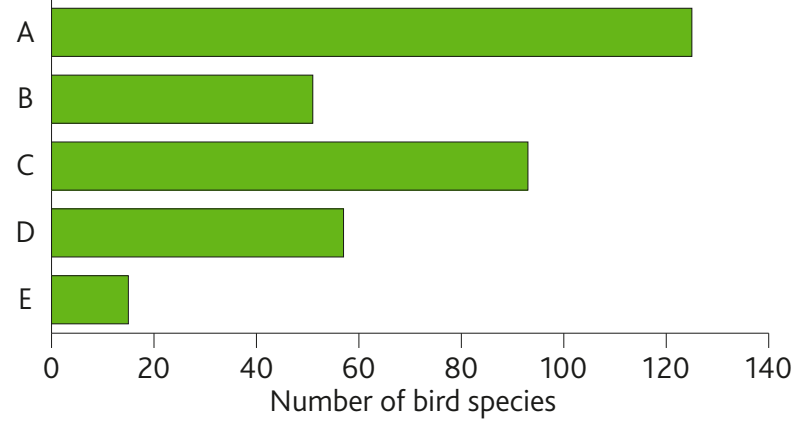

Figure 16. Classification of species of the avian community after the habitats they populate $(A=$ large forests/parks which include (or not) large water surfaces; $\mathrm{B}=$ open lands, with a low vegetation; $\mathrm{C}=$ small parks, narrow green areas, private gardens; $D=$ areas with water (rivers, lakes) with low or average high vegetation; $\mathrm{E}=$ prevalent built areas, with a scarce vegetation

The phenological division of the avian community of Bucharest was made: sedentary birds (those which stay in these ecosystems all along the year), summer guests (migratory birds which remain and nestle in Bucharest), winter guests (birds which visit the city only in winter) and transit birds (migratory birds which stop in the city for resting and foraging while crossing in spring and in autumn (Figure 15, Table 2).

Analyzing the avifauna (1991-2006), the authors took into account several habitats characteristic of the city, not including surrounding areas, which we have classified into five major categories (Figure 16, Table 2): A=large forests/parks, which include (or not) large water surfaces; $\mathrm{B}=$ open lands, with low vegetation; $\mathrm{C}=$ small parks, narrow green areas, private gardens with low grassy vegetation and old trees; $\mathrm{D}=$ areas with water (rivers, lakes) with a low or average high vegetaion; $\mathrm{E}=$ prevalent built areas, with scarce vegetation.

Tree and shrub vegetation, of different age, provides nesting and resting places, but also various foraging sources for the four bird categories: Sedentary, Summer guest, Winter guest, migratory birds (long distance migrating species of birds).

Vast forests and parks, which include large areas of water, are populated with over 120 species of birds. This category includes large parks of the city aged over 100 years as Cismigiu, Kiseleff and Herastrau, or parks under 40-70 years as Youth Park, Polytechnic Park, Izvor Park or Alexandru Ioan Cuza Park (Titan Park or IOR Park), plus other midsized parks of different ages.

Till 1991, these areas were unaltered, in which there were also some day raptor birds as Milvus milvus, Pernis apivorus, Buteo buteo of night raptor birds as Strix aluco, Otus scops were present, either in transit or nesting, all of them species places at the top of the food chain. The presence of the prey birds is an indicator of some stable biocenoses, with a large biodiversity, which provides the source of food and nesting. Along the time, their surface was slightly diminished by construction of buildings, but generally, the changes made by the maintenance works, tree cuts or maintaining the grassy vegetation, did not alter at a large scale the components of avifauna. As a matter of fact, in this kind of habitat, similar to a forest, are living 68 species of insectivorous birds, as well as some species of baccivore-granivorous and/or omnivorous birds.

In terms of quality, summer guest birds are prevalent within avifauna, as nesting ones, most of them insectivores, being the proof of the high biodiversity which still exists here, both flora and fauna.

The absence of the large day and night birds of prey, after 2006 , can be explained by the fact that these large green areas were, in time, surrounded by the residential areas, which isolate them from the forest and land net which around Bucharest. Before 1990, among them there were free lanes so that a natural flow of immigration and emigration fauna existed between the city and the natural green areas around Bucharest, without obstacles, allowing biocoenoses to remain stable through this natural flow of wildlife. Birds of prey need large territories for foraging, sometimes of tens of $\mathrm{km}^{2}$, with low vegetation. Large park areas, almost entirely covered with trees and shrubs, do not always provide an optimum habitat for foraging, so the birds must seek new hunting territories outside the city. Daily crossings between the places of resting 
Table 2. The birds present in the city of Bucharest in 1991 and 2006 (Papadopol, Petrescu, 1991; Papadopol, Petrescu, 2006). Legend: $\boldsymbol{\Delta}$ =species presence; $\triangle$ =species absence.

\begin{tabular}{|c|c|c|c|c|c|c|c|}
\hline & \multicolumn{2}{|l|}{ BIRD SPECIES } & ORDER & FENOLOGY & HABITAT & 1991 & 2006 \\
\hline 1 & \multicolumn{2}{|c|}{ Accipiter nisus (Eurasian sparrowhawk) } & Accipitriformes & Wg & $A, B, C, E$ & $\boldsymbol{\Delta}$ & $\Delta$ \\
\hline 2 & \multicolumn{2}{|c|}{ Acrocephalus scirpaceus (Eurasian reed-warbler) } & Passeriformes & $\mathrm{Sg}$ & $A, D$ & $\boldsymbol{\Delta}$ & $\boldsymbol{\Delta}$ \\
\hline 3 & \multicolumn{2}{|c|}{ Acrocephalus arundinaceus (Great reed warbler) } & Passeriformes & $\mathrm{Sg}$ & $A, C, D$ & $\Delta$ & $\Delta$ \\
\hline 4 & \multicolumn{2}{|c|}{ Aegithalos caudatus (Long-tailed tit) } & Passeriformes & $\mathrm{Se}$ & $A, B, C, D$ & $\Delta$ & $\Delta$ \\
\hline 5 & \multicolumn{2}{|c|}{ Alcedo atthis (Common kingfisher) } & Coraciiformes & $\mathrm{Se}$ & $A, D$ & $\Delta$ & $\triangle$ \\
\hline 6 & \multicolumn{2}{|c|}{ Anas crecca (Common teal) } & Anseriformes & Wg & $A, D$ & $\triangle$ & $\Delta$ \\
\hline 7 & \multicolumn{2}{|c|}{ Anas acuta (Northern pintail) } & Anseriformes & $\operatorname{Tr}$ & $A, D$ & $\triangle$ & $\Delta$ \\
\hline 8 & \multicolumn{2}{|c|}{ Anas platyrhynchos (Mallard) } & Anseriformes & $\mathrm{Se}$ & $A, D$ & $\Delta$ & $\Delta$ \\
\hline 9 & \multicolumn{2}{|c|}{ Anthus trivialis (Tree pipit) } & Passeriformes & $\mathrm{Sg}, \mathrm{Tr}$ & $A, B, C$ & $\boldsymbol{\Delta}$ & $\Delta$ \\
\hline 10 & \multicolumn{2}{|c|}{ Anthus spinoletta (Water pipit) } & Passeriformes & $\mathrm{Sg}, \mathrm{Tr}$ & $A, B, C$ & $\triangle$ & $\Delta$ \\
\hline 11 & \multicolumn{2}{|c|}{ Apus apus (Common swift) } & Caprimulgiformes & Sg & $A, C, D, E$ & $\Delta$ & $\Delta$ \\
\hline 12 & \multicolumn{2}{|c|}{ Ardeola ralloides (Squacco heron) } & Pelecaniformes & $\mathrm{Sg}$ & $A, D$ & $\Delta$ & $\boldsymbol{\Delta}$ \\
\hline 13 & \multicolumn{2}{|c|}{ Ardea cinerea (Grey heron) } & Pelecaniformes & $\mathrm{Sg}$ & $A, D$ & $\Delta$ & $\Delta$ \\
\hline 14 & \multicolumn{2}{|c|}{ Asio otus (Long-eared owl) } & Strigiformes & $\mathrm{Se}$ & $A, D$ & $\boldsymbol{\Delta}$ & $\Delta$ \\
\hline 15 & \multicolumn{2}{|c|}{ Athene noctua (Little owl) } & Strigiformes & $\mathrm{Se}$ & $A, C, E$ & $\Delta$ & $\Delta$ \\
\hline 16 & \multicolumn{2}{|c|}{ Aythya nyroca (Ferruginous duck) } & Anseriformes & Sg & A, D & $\triangle$ & $\Delta$ \\
\hline 17 & \multicolumn{2}{|c|}{ Aythya ferina (Common pochard) } & Anseriformes & $\mathrm{Sg}$ & $A, D$ & $\triangle$ & $\Delta$ \\
\hline 18 & \multicolumn{2}{|c|}{ Bombycilla garrulus (Bohemian waxwing) } & Passeriformes & $W g$ & $A, B, C, E$ & $\Delta$ & $\Delta$ \\
\hline 19 & \multicolumn{2}{|c|}{ Buteo buteo (Common buzzard) } & Accipitriformes & $\mathrm{Se}, \mathrm{Tr}$ & $A, B, C$ & $\Delta$ & $\triangle$ \\
\hline 20 & \multicolumn{2}{|c|}{ Charadrius dubius (Little ringed plove) } & Charadriiformes & Sg & $A, D$ & $\Delta$ & $\triangle$ \\
\hline 21 & \multicolumn{2}{|c|}{ Caprimulgus europaeus (European nightjar) } & Caprimulgiformes & $\mathrm{Sg}, \mathrm{Tr}$ & $A, B, C$ & $\Delta$ & $\triangle$ \\
\hline 22 & \multicolumn{2}{|c|}{ Carduelis carduelis (European goldfinch) } & Passeriformes & $\mathrm{Se}, \mathrm{Tr}$ & $A, B, C$ & $\Delta$ & $\Delta$ \\
\hline 23 & Carduelis cannabina & rasian linnet) & Passeriformes & $\mathrm{Se}, \mathrm{Tr}$ & $A, B, C$ & $\Delta$ & $\Delta$ \\
\hline 24 & Carduelis chloris (E & ean greenfinch) & Passeriformes & $\mathrm{Se}$ & $A, B, C$ & $\Delta$ & $\Delta$ \\
\hline 25 & Carduelis spinus (Eu & an siskin) & Passeriformes & $\mathrm{Sg}$ & $A, B, C$ & $\Delta$ & $\Delta$ \\
\hline 26 & Certhia familiaris (E & ian treecreeper) & Passeriformes & $\mathrm{Se}$ & $A, B, C$ & $\Delta$ & $\Delta$ \\
\hline 27 & Ciconia ciconia (Wr & stork) & Ciconiiformes & $\mathrm{Sg}, \mathrm{Tr}$ & $B, D$ & $\Delta$ & $\triangle$ \\
\hline 28 & Circus aeruginosus & stern marsh-harrier) & Accipitriformes & $\mathrm{Sg}$ & $B, D$ & $\triangle$ & $\Delta$ \\
\hline 29 & Chlidonias hybrida & (Whiskered tern) & Charadriiformes & $\mathrm{Sg}$ & $A, D$ & $\triangle$ & $\Delta$ \\
\hline 30 & Coccothraustes coc & raustes (Hawfinch) & Passeriforme & Se & $A, B, C$ & $\Delta$ & $\Delta$ \\
\hline 31 & Columba palumbus & mmon woodpigeon) & Columbiformes & $\mathrm{Sg}$ & $A, B, C$ & $\Delta$ & $\triangle$ \\
\hline 32 & Columba livia dome & (Rock dove) & Columbiformes & $\mathrm{Se}$ & $C, E$ & $\Delta$ & $\Delta$ \\
\hline 33 & Coracias garrulus (E & sean roller) & Coraciiformes & $\mathrm{Sg}$ & $A, B, C, D$ & $\boldsymbol{\Delta}$ & $\triangle$ \\
\hline 34 & Corvus corone sard & s (Carrion crow) & Passeriformes & $\mathrm{Se}$ & $A, B, C, E$ & $\Delta$ & $\Delta$ \\
\hline 35 & Corvus frugilegus (P & & Passeriformes & Se & $A, B, C$ & $\Delta$ & $\Delta$ \\
\hline 36 & Corvus monedula (E & sian jackdaw) & Passeriformes & $\mathrm{Se}$ & $A, B, C, D, E$ & $\Delta$ & $\Delta$ \\
\hline 37 & Cuculus canorus (C & non cuckoo) & Cuculiformes & $\mathrm{Sg}$ & $A, B, C$ & $\Delta$ & $\Delta$ \\
\hline 38 & Crex crex (Corncrak & & Gruiformes & $\mathrm{Sg}$ & $A, B, C$ & $\Delta$ & $\triangle$ \\
\hline 39 & Cygnus olor (Mute & & Anseriformes & $\mathrm{Sg}$ & $A, D$ & $\triangle$ & $\Delta$ \\
\hline 40 & Delichon urbicum (I & hern house-martin) & Passeriformes & $\mathrm{Sg}$ & $C, E$ & $\Delta$ & $\Delta$ \\
\hline 41 & Dendrocopos major & eater spotted woodpecker) & Piciformes & Se & $A, C$ & $\Delta$ & $\Delta$ \\
\hline 42 & Dendrocopos syriac & yrian woodpecker) & Piciformes & $\mathrm{Se}$ & $A, C$ & $\Delta$ & $\Delta$ \\
\hline 43 & Dryobates minor (G & er spotted woodpecker) & Piciformes & $\mathrm{Se}$ & $A, C$ & $\boldsymbol{\Delta}$ & $\triangle$ \\
\hline 44 & Egretta alba (Great & te egret) & Pelecaniformes & $\operatorname{Tr}$ & $A, D$ & $\triangle$ & $\Delta$ \\
\hline
\end{tabular}




\begin{tabular}{|c|c|c|c|c|c|c|}
\hline & BIRD SPECIES & ORDER & FENOLOGY & HABITAT & 1991 & 2006 \\
\hline 45 & Egretta garzetta (Little egret) & Pelecaniformes & $\operatorname{Tr} / \mathrm{Sg}$ & $A, D$ & $\triangle$ & $\Delta$ \\
\hline 46 & Emberiza citrinella (Yellowhammer) & Passeriformes & $\mathrm{Se}, \mathrm{Wg}$ & $A, B, C$ & $\Delta$ & $\Delta$ \\
\hline 47 & Emberiza hortulana (Ortolan bunting) & Passeriformes & Sg & $A, B, C$ & $\Delta$ & $\Delta$ \\
\hline 48 & Emberiza schoeniclus (Reed bunting) & Passeriformes & Wg & $A, D$ & $\Delta$ & $\triangle$ \\
\hline 49 & Erithacus rubecula (European robin) & Passeriformes & $\mathrm{Sg}, \mathrm{Wg}$ & $A, B, C$ & $\Delta$ & $\Delta$ \\
\hline 50 & Falco tinnunculus (Common kestrel) & Falconiformes & $\mathrm{Se}$ & $A, C$ & $\Delta$ & $\Delta$ \\
\hline 51 & Falco vespertinus (Red footed falcon) & Falconiformes & $\mathrm{Sg} \operatorname{Tr}$ & $A, C$ & $\triangle$ & $\Delta$ \\
\hline 52 & Falco subbuteo (Eurasian hobby) & Falconiformes & $\mathrm{Sg} \operatorname{Tr}$ & $A, C$ & $\triangle$ & $\Delta$ \\
\hline 53 & Ficedula albicollis (Collared flycatcher) & Passeriformes & $\operatorname{Tr}$ & $A, B, C$ & $\Delta$ & $\triangle$ \\
\hline 54 & Ficedula hypoleuca (European pied flycatcher) & Passeriformes & $\mathrm{Sg}, \mathrm{Tr}$ & $A, B, C$ & $\Delta$ & $\triangle$ \\
\hline 55 & Fringilla coelebs (Eurasian chaffinch) & Passeriformes & $\mathrm{Se}$ & A, C & $\Delta$ & $\Delta$ \\
\hline 56 & Fringilla montifringilla (Brambling) & Passeriformes & Wg & $A, C$ & $\Delta$ & $\Delta$ \\
\hline 57 & Fulica atra (Common coot) & Gruiformes & $\mathrm{Sg}$ & $A, D$ & $\Delta$ & $\Delta$ \\
\hline 58 & Gallinago gallinago (Common snipe) & Charadriiformes & $\mathrm{Sg}$ & $A, D$ & $\Delta$ & $\triangle$ \\
\hline 59 & Gallinula chloropus (Common moorhen) & Gruiformes & Se & $A, D$ & $\Delta$ & $\Delta$ \\
\hline 60 & Galerida cristata (Crested lark) & Passeriformes & $\mathrm{Se}$ & $A, D$ & $\Delta$ & $\Delta$ \\
\hline 61 & Garrulus glandarius (Eurasian jay) & Passeriformes & $\mathrm{Se}$ & $A, C$ & $\Delta$ & $\Delta$ \\
\hline 62 & Gavia arctica (Arctic loon) & Gaviiformes & $\mathrm{Wg}, \mathrm{Tr}$ & $A, D$ & $\Delta$ & $\triangle$ \\
\hline 63 & Ixobrychus minutus (Little bittern) & Pelecaniformes & $\mathrm{Sg}$ & $A, D$ & $\Delta$ & $\triangle$ \\
\hline 64 & Jynx torquilla (Eurasian wryneck) & Piciformes & $\mathrm{Sg}$ & $A, D$ & $\Delta$ & $\Delta$ \\
\hline 65 & Hippolais icterina (Icterine warbler) & Passeriformes & Sg & $A, B, C, D$ & $\Delta$ & $\Delta$ \\
\hline 66 & Hippolais pallida (Eastern olivaceous warbler) & Passeriformes & Sg & $A, C$ & $\Delta$ & $\Delta$ \\
\hline 67 & Hirundo rustica (Barn swallow) & Passeriformes & Sg & $A, B, C, E$ & $\Delta$ & $\Delta$ \\
\hline 68 & Lanius collurio (Red-backed shrike) & Passeriformes & $\mathrm{Sg}$ & $A, C$ & $\Delta$ & $\triangle$ \\
\hline 69 & Lanius minor (Lesser grey shrike) & Passeriformes & $\mathrm{Sg}$ & $B, D$ & $\Delta$ & $\triangle$ \\
\hline 70 & Larus cachinnans (Caspian gull) & Charadriiformes & $\mathrm{Se}$ & $A, C, D$ & $\Delta$ & $\Delta$ \\
\hline 71 & Larus canus (Mew gull) & Charadriiformes & $W g$ & $A, C, D$ & $\Delta$ & $\Delta$ \\
\hline 72 & Larus marinus (Great Black-backed Gull) & Charadriiformes & Wg & $A, C, D$ & $\triangle$ & $\Delta$ \\
\hline 73 & Larus ridibundus (Black-headed gull) & Charadriiformes & $\mathrm{Se}$ & $A, C, D$ & $\Delta$ & $\Delta$ \\
\hline 74 & Leiopicus medius (Middle spotted woodpecker) & Piciformes & $\mathrm{Se}$ & A, C & $\Delta$ & $\Delta$ \\
\hline 75 & Loxia curvirostra (Red crossbill) & Passeriformes & Wg & A & $\Delta$ & $\Delta$ \\
\hline 76 & Lullula arborea (Wood Lark) & Passeriformes & $W g$ & $A, C$ & $\Delta$ & $\triangle$ \\
\hline 77 & Luscinia luscinia (Trush nightingale) & Passeriformes & $\mathrm{Sg}$ & $A, C$ & $\Delta$ & $\Delta$ \\
\hline 78 & Luscinia megarhynchos (Common nightingale) & Passeriformes & $\mathrm{Sg}$ & $A, C$ & $\Delta$ & $\Delta$ \\
\hline 79 & Mareca penelope (Eurasian wigeon) & Anseriformes & $\mathrm{Wg}-\mathrm{Tr}$ & $A, D$ & $\Delta$ & $\Delta$ \\
\hline 80 & Mareca strepera (Gadwall) & Anseriformes & $\mathrm{Sg}$ & $A, D$ & $\Delta$ & $\triangle$ \\
\hline 81 & Miliaria calandra (Corn bunting) & Passeriformes & $\mathrm{Sg}$ & $A, B$ & $\Delta$ & $\triangle$ \\
\hline 82 & Milvus milvus (Red kite) & Accipitriformes & $\operatorname{Tr}$ & $A, C$ & $\Delta$ & $\triangle$ \\
\hline 83 & Motacilla alba (White wagtail) & Passeriformes & $\mathrm{Sg}, \mathrm{Tr}$ & $A, B, C$ & $\Delta$ & $\Delta$ \\
\hline 84 & Motacilla cinerea (Grey wagtail) & Passeriformes & $\operatorname{Tr}, \mathrm{Sg}$ & $A, B, C$ & $\Delta$ & $\triangle$ \\
\hline 85 & Motacilla flava (Yellow wagtail) & Passeriformes & $\mathrm{Sg}, \mathrm{Tr}$ & $A, B, C$ & $\Delta$ & $\Delta$ \\
\hline 86 & Muscicapa striata (Spotted flycatcher) & Passeriformes & $\mathrm{Sg}$ & $\mathrm{A}, \mathrm{C}$ & $\Delta$ & $\Delta$ \\
\hline 87 & Nycticorax nycticorax (Black-crowned night heron) & Pelecaniformes & $\mathrm{Sg}$ & $A, D$ & $\Delta$ & $\Delta$ \\
\hline 88 & Oriolus oriolus (Eurasian golden oriole) & Passeriformes & $\mathrm{Sg}$ & $A, C, E$ & $\Delta$ & $\Delta$ \\
\hline 89 & Otus scops (Eurasian scops owl) & Strigiformes & Sg & $A, C$ & $\Delta$ & $\triangle$ \\
\hline 90 & Parus caeruleus (Blue tit) & Passeriformes & Se & $A, C$ & $\Delta$ & $\Delta$ \\
\hline
\end{tabular}




\begin{tabular}{|c|c|c|c|c|c|c|}
\hline & BIRD SPECIES & ORDER & FENOLOGY & HABITAT & 1991 & 2006 \\
\hline 91 & Parus lugubris (Sombre tit) & Passeriformes & Se & $A, C$ & $\Delta$ & $\triangle$ \\
\hline 92 & Parus major (Great tit) & Passeriformes & Se & $A, C$ & $\Delta$ & $\Delta$ \\
\hline 93 & Passer domesticus (House sparrow) & Passeriformes & Se & $C, E$ & $\Delta$ & $\Delta$ \\
\hline 94 & Passer montanus (Eurasian tree sparrow) & Passeriformes & Se & $A, C$ & $\Delta$ & $\Delta$ \\
\hline 95 & Perdix perdix (Grey partridge) & Galiiformes & $\mathrm{Se}$ & $A, B, C$ & $\Delta$ & $\triangle$ \\
\hline 96 & Pernis apivorus (European honey-buzzard) & Accipitriformes & $\mathrm{Tr}$ & $A$ & $\Delta$ & $\triangle$ \\
\hline 97 & Phalacrocorax carbo (Great cormorant) & Suliformes & Sg & $A, D$ & $\triangle$ & $\Delta$ \\
\hline 98 & Phylloscopus sibilatrix (Wood warbler) & Passeriformes & $\mathrm{Sg} \operatorname{Tr}$ & $A$ & $\Delta$ & $\Delta$ \\
\hline 99 & Phoenicurus ochruros (Black redstart) & Passeriformes & Sg & $A, C$ & $\Delta$ & $\Delta$ \\
\hline 100 & Phoenicurus phoenicurus (Common redstart) & Passeriformes & Sg & $A, B, C, D, E$ & $\Delta$ & $\Delta$ \\
\hline 101 & Pica pica (Black-billed magpie) & Passeriformes & Se & $A, C, E$ & $\Delta$ & $\Delta$ \\
\hline 102 & Picus canus (Grey-headed woodpecker) & Piciformes & $\mathrm{Se}$ & $A, C$ & $\Delta$ & $\Delta$ \\
\hline 103 & Picus viridis (Eurasian green woodpecker) & Piciformes & Se & $A, C$ & $\Delta$ & $\boldsymbol{\Delta}$ \\
\hline 104 & Podiceps cristatus (Great crested grebe) & Podicipediformes & Sg & $A, D$ & $\Delta$ & $\triangle$ \\
\hline 105 & Porzana porzana (Spoted crake) & Gruiformes & Sg & $A, D$ & $\Delta$ & $\triangle$ \\
\hline 106 & Phylloscopus collybita (Common chiffchaff) & Passeriformes & $\mathrm{Sg}, \mathrm{Tr}$ & $A, C$ & $\Delta$ & $\Delta$ \\
\hline 107 & Phylloscopus trochilus (Willow warbler) & Passeriformes & $\operatorname{Tr}$ & $A, C$ & $\Delta$ & $\Delta$ \\
\hline 108 & Prunella modularis (Hedge accentor) & Passeriformes & $\mathrm{Wg}$ & $A, B, C, D$ & $\Delta$ & $\triangle$ \\
\hline 109 & Pyrrhula pyrrhula (Eurasian bullfinch) & Passeriformes & Wg & $A, B, C$ & $\Delta$ & $\Delta$ \\
\hline 110 & Rallus aquaticus (Western water rail) & Gruiformes & Sg & $\mathrm{D}$ & $\Delta$ & $\triangle$ \\
\hline 111 & Remiz pendulinus (Eurasian penduline-tit) & Passeriformes & $\mathrm{Sg} / \mathrm{Se}$ & $A, B, C, D$ & $\Delta$ & $\triangle$ \\
\hline 112 & Riparia riparia (Sand Martin) & Passeriformes & $\mathrm{Sg}$ & $\mathrm{C}$ & $\Delta$ & $\triangle$ \\
\hline 113 & Scolopax rusticola (Eurasian woodcock) & Charadriiformes & $\operatorname{Tr}$ & $A, C, D$ & $\Delta$ & $\Delta$ \\
\hline 114 & Sitta europaea caesia (Wood nuthatch) & Passeriformes & $\mathrm{Se}$ & $A, B, C$ & $\Delta$ & $\Delta$ \\
\hline 115 & Spatula clypeata (Northern shoveler) & Anseriformes & Sg & $A, D$ & $\Delta$ & $\triangle$ \\
\hline 116 & Spatula querquedula (Garganey) & Anseriformes & Sg & $A, D$ & $\Delta$ & $\triangle$ \\
\hline 117 & Streptopelia decaocto (Eurasian collared-dove) & Columbiformes & $\mathrm{Se}$ & $C, D, E$ & $\Delta$ & $\Delta$ \\
\hline 118 & Streptopelia turtur (European turtle-dove) & Columbiformes & Sg & $C, D, E$ & $\Delta$ & $\triangle$ \\
\hline 119 & Strix aluco (Tawny owl) & Strigiformes & $\mathrm{Se}$ & $A, C$ & $\Delta$ & $\triangle$ \\
\hline 120 & Sturnus vulgaris (Common starling) & Passeriformes & $\mathrm{Sg}, \mathrm{Se}$ & $A, B, C$ & $\Delta$ & $\Delta$ \\
\hline 121 & Sylvia atricapilla (Blackcap) & Passeriformes & Sg & $A, B, C$ & $\Delta$ & $\Delta$ \\
\hline 122 & Sylvia borin (Garden warbler) & Passeriformes & $\mathrm{Sg} \operatorname{Tr}$ & $A, B, C$ & $\Delta$ & $\Delta$ \\
\hline 123 & Sylvia communis (Common whitethroat) & Passeriformes & $\mathrm{Sg} \operatorname{Tr}$ & $A, B, C, D$ & $\Delta$ & $\Delta$ \\
\hline 124 & Sylvia curruca (Lesser whitethroat) & Passeriformes & $\mathrm{Sg} \operatorname{Tr}$ & $A, B, C$ & $\Delta$ & $\Delta$ \\
\hline 125 & Sylvia nisoria (Barred warbler) & Passeriformes & $\mathrm{Sg} \operatorname{Tr}$ & $A, B, C$ & $\Delta$ & $\Delta$ \\
\hline 126 & Tachybaptus ruficollis (Little grebe) & Podicipediformes & Se & $A, D$ & $\triangle$ & $\Delta$ \\
\hline 127 & Tringa ochropus (Green sandpiper) & Charadriiformes & $\mathrm{Tr}$ & $A, D$ & $\Delta$ & $\triangle$ \\
\hline 128 & Troglodytes troglodytes (Winter wren) & Passeriformes & $\mathrm{Sg}, \mathrm{Tr}$ & $A, B, C$ & $\Delta$ & $\Delta$ \\
\hline 129 & Turdus iliacus (Redwing) & Passeriformes & $\mathrm{Wg}, \mathrm{Tr}$ & $A, B, C$ & $\Delta$ & $\Delta$ \\
\hline 130 & Turdus merula (Eurasian blackbird) & Passeriformes & $\mathrm{Se}, \mathrm{Sg}, \mathrm{Tr}$ & $A, B, C, D, E$ & $\Delta$ & $\Delta$ \\
\hline 131 & Turdus philomelos (Song trush) & Passeriformes & $\mathrm{Sg}$ & $A, B, C$ & $\Delta$ & $\Delta$ \\
\hline 132 & Turdus pilaris (Fieldfare) & Passeriformes & $\mathrm{Tr}, \mathrm{Se}$ & $A, C$ & $\Delta$ & $\Delta$ \\
\hline 133 & Turdus viscivorus (Mistle thrush) & Passeriformes & $\operatorname{Tr}$ & $A, C$ & $\Delta$ & $\Delta$ \\
\hline 134 & Upupa epops (Common hoopoe) & Bucerotiformes & Sg & $A, B, C, D$ & $\Delta$ & $\triangle$ \\
\hline 135 & Vanellus vanellus (Northern lapwing) & Charadriiformes & Sg & $A, D$ & $\Delta$ & $\triangle$ \\
\hline
\end{tabular}

Source: Data collected by authors 
or nesting and the foraging territory are blocked by numerous tall buildings, brightly lit, or by high traffic associated with high noise (ring road), which represent limiting factors for birds. The response to the high stress of these limiting factors is that birds leave these habitats that no longer provide optimal environmental conditions.

Small parks, narrow green spaces, private gardens with low herbaceous vegetation and old trees form a class of preferred habitat for over 75 bird species which have found shelter, food or nesting spot. As it can be seen on satellite maps of vegetation areas of 1991, the largest area of vegetation in Bucharest is occupied by a mosaic of green islands, isolated by buildings and streets, that are scattered randomly over the entire city. This mosaic was represented by houses with private gardens, small parks, squares, or by the street lining which separate and protect, from neighborhoods or heavy traffic arteries, the residential areas built until 1991.

Between 1970-1990, Bucharest underwent an extensive modernization action, which involved an unprecedented aggression on small buildings and green spaces. Central part of the city was demolished and hundreds of old houses with greenery around them but also with private backyards, where they were stable biocenosed for hundreds of years, were destroyed. In their place appeared a mosaic of bare land, which, in a few years, began to be colonized by pioneer herbaceous vegetation and several species of shrubs. All these vacant lands, left in ruins, were occupied successively by species of insects and other anthropophilous invertebrates, mammals, reptiles and birds. Simultaneously with the demolition of old buildings, on the outskirts residential areas begin to be build, designed without green areas, only with tree curtains that separate the buildings from each other or from the streets. Untill 1990, the construction of these residential areas on the outskirts produced a strong fragmentation of natural ecosystems that surrounded the city and who had a stable biocenosis. In 1991-2006 period, all vacant terraines appeared after demolition, associated with other uncovered lands, with low vegetation, became the target of real estate investments, and many of them disappeared, being covered with parking lots, buildings and large residential areas, which explains

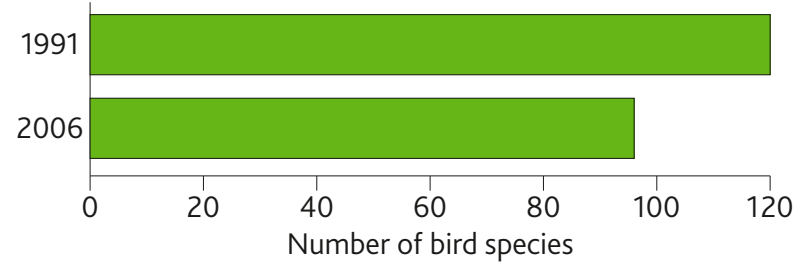

Figure 17. Comparative diagram of the number of bird species, for 1991 and 2006 the absence of over 17 species of insectivorous or carnivorous birds whose life was linked to trees and shrubs, insects and other species of fauna (Figure 17).

Water areas (rivers, lakes) with low or average high vegetation, associated with large areas of water from parks, are a category of habitat preferred by 87 bird species in Bucharest.

Bucharest hydrographic network includes large water reservoirs on both Colentina, decorated with many ponds, and Dambovita River that crosses Bucharest. In 1980, Dambovita underwent a radical change, the banks were embanked and concreted, and all the terrestrial and aquatic biocoenoses developed on the left and right banks of this river were destroyed. After 1990, the recovering of the aquatic biocenosis have began; the river flow within the city was populated with fauna naturally brought by the upstream water flow, and also the first vertrebrate colonizer of the river appear, Anas platyrhynchos (Mallard), as anthropophilous species, nesting on Dambovita. Also during the summer, this river flow is the foraging area for Larus cachinnans, nesting species on the buildings of $\mathrm{Bu}$ charest since 1974. In the cold season, there is wintering place, inside the city, for Larus ridibundus, Fulica atra, Anas platyrhynchos and Larus cachinnans.

In the hydrographic management plan of Dambovita River of the ' 8 os, it was also included the arranging of the Vacaresti Lake, a large stretch of water, which was to be supplied from Dambovita. After 1990, the work was abandoned, part of the lake basin bordered by concrete embankments is covered by water provided by its own springs and rain. In time, vacant nude land, was covered by vegetation and partially by water and colonized by a rich fauna. Today, it is a well stable biocenosis, where more than 115 bird species live, along with many other species of invertebrates and vertebrates. The appearance of this surface of about 170 ha of water and vegetation encouraged the Anseriformes species to seek new places for nesting and foraging in Bucharest (Figure 18).

Since 1990, there were remarked species as: $A y$ thya nyroca, Aythya ferina, Cygnus olor, not reported in Bucharest till then. Also here, species which prefer aquatic environment were also observed: Fulica atra, Chlydonias hybridus, Podiceps cristatus, Egretta garzetta, Egretta alba, Phalacrocorax carbo, Ardea cinerea, Ardea purpurea, etc. The emergence and development of the wetlands with a large surface, similar to a natural wetland, made it possible to live within the city or to nest more than 15 species of waterfowl, unreported until 2006. Subsequently, Vacaresti Lake was proposed for the creation of an Urban Natural Park, as a protected area, recognized today.

Predominantly built areas, with little vegetation, are represented by the old buildings and the build- 


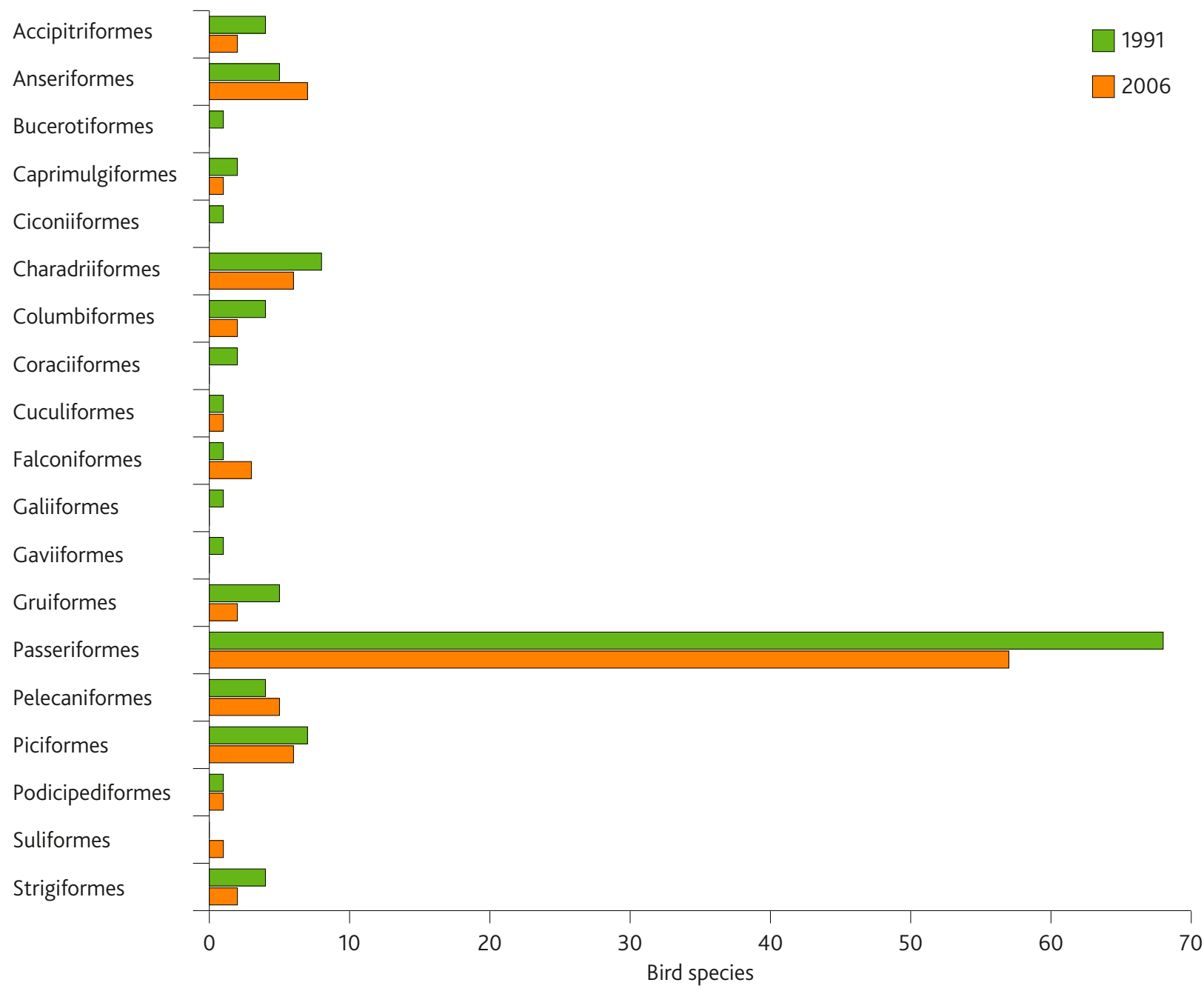

Figure 18. The number of birds per order, present in Bucharest in 1991 and 2006

ings of the residential areas. These habitats are preferred by some bird species adapted to rest or nest using these resources. Passer domesticus, Hirundo rustica, Delichon urbica, Apus apus, Phoenicurus ochruros gibraltariensis, Athene noctua, Coloeus monedula, Falco tinnunculus and Larus cachinnans are the species which prefer to nest in/on the buildings of Bucharest. Between 1991-2006 the number of nesting places of Delichon urbica and Hirundo rustica drastically decreased, on one hand, because of the lack of the optimum nesting places, by the demolition of the old buildings with roof and eaves, because of the lack of the material necessary for the nest building (water, mud, vegetal fibers), and, on the other hand, the lack of food, represented exclusively by insects. At first, Larus cachinnans nested on the roof of the high buildings of Bucharest, and now it nests on the blocks of flats around Dambovita River or in the parks with large water surfaces. Coloeus monedula, nesting species, was frequent till 1990, today it is quite rare, because the lack of the nesting places, because it prefers the roofs with chimnies. Because of the modern type of domestic heating, new buildings do not have chimnies, or those already built of metal, covered, and do not allow the nest construction. Falco tinnunculus is a cosmopolitan bird that nests here since 1990 on the highest building in Bucharest, Palace of Parliament (House of the People).

It is known that, ecologically, each species of the ecosystem provides services directly or indirectly, bringing benefits to both the environment and people. Functions of birds in urban environment can be grouped into three categories: ecological, psychological and social (Idilfitri et al., 2014). Insectivorous birds help plants by the control and the quantity of insects they eat from tree bark, leaves and branches, while the omnivorous birds control the populations of vertebrates (micromammals, reptiles, etc) penetrating the residential areas. Psychologically, chirping birds and their game on twigs and soil, improve the viewers' state of relaxation. And socially, the abundance of the bird species in green areas increase the value of the area both by aesthetic appearance and by economic/estate aspect. 


\section{Conclusion}

The urban vegetation adequate monitoring and conservation are great current ecological challenges due to the fact that it is an important key to understand and manage urban development. In the field of environmental protection and vegetation conservation, contemporary trends are related to the use of recent remote sensing technologies applied in order to realize scientific and research aims and tasks.

The modern technologies provide many useful data to the urban planners and to other decision makers on the urban green spaces' dynamics and on the decisions to be made (areas that require replanting, new planting locations etc.).

This paper studied the efficacity of satellite imagery for extracting urban trees, a necessary action in the context of an accelerate rate of urbanisation of the capital town. The paper proved that the satellite images represent a suitable technology and a viable source of information for urban planners and other decision makers to evaluate, enhance urban landscape patterns and facilitate a better understanding of the current spatial distribution and typology of trees in $\mathrm{Bu}-$ charest Municipality.

In this study, the results of satellite images have demonstrated the present state of the environment and the effects upon it (fragmentation, state of health) in the Bucharest Municipality. Therefore, based on these results, control and protection measures for the vegetation cover of the municipality of Bucharest will be proposed. Furthermore, these proposals will be an important element in the process of decision making for the conservation of urban vegetation.

Another object of interest in this study was the correlation between habitats and bird species (those being chosen as a quality indicator of the environment).

Within the period 1991-2006, from the ecosystems of Bucharest, 38 bird species, most of them Passeriformes, alongside Strigiformes, Falconiformes and Piciformes, have disappeared; they were characteristic to tree and shrub vegetation formed in large and groups, of various ages, fructifications and rich canopy. Controversely, the emergence and development of the wetland Vacaresti Delta, with a large-area, similar to a natural wetland, led to the emergence within the city of more than 15 species of waterfowl unreported until 2006.

Birds have a significant biological and economic value through the benefits they bring, having a major role in controlling insect species and pollination. Protecting and preserving the habitats they live in, it also increases the biological value of the ecosystems and ecosystem services, and social values of urban communities. One of eight bird species is threatened with extinction and their number continues to grow because of the habitat destruction, climate change and invasive species (BirdLife International, 2015).

Therefore, future work should concentrate on developing an approach by which to identify a solution to make more accessible the urban habitats for several species.

\section{References}

Alberti, M., Marzluff, J. M. 2004. Ecological resilience in urban ecosystems: linking urban patterns to human and ecological functions. Urban Ecosystems 7, 241-265.

Agrawal, M., Reddy, D. S., Prasad, R. C. 2016. Automatic extraction of mangrove vegetation from optical satellite data. Int. Arch. Photogramm. Remote Sens. Spatial Inf. Sci. XLI-B8, 555-561.

Bartens, J., Day, S. B. Harris J. R., Dove J. E., Wynn T.M. 2008. Can Urban Tree Roots Improve Infiltration through Compacted Subsoils for Stormwater Management? J. of Environmental Quality 37, 6, 2048-2057.

Bellakaout, A., Cherkaoui, M., Ettarid, M., Touzani, A. 2016. Automatic 3D extraction of buildings, vegetation and roads from LIDAR Data. Int. Arch. Photogramm. Remote Sens. Spatial Inf. Sci. XLI-B3, 173180.

Bino, G., Levin, N., Darawshi, S., Van Der Hal, N., Reich-Solomon, A., Kark, S. 2008. Accurate prediction of bird species richness patterns in an urban environment using Landsat-derived NDVI and spectral unmixing. Int $J$ of Remote Sensing 29, 13, 3675-3700.

Bornstein, R. D. 1968. Observations of the urban heat island effect in New York City. J. of Applied Meteorology 7, 575-582.

Burchfield, E., Nay, J. J., Gilligan, J. 2016. Application of machine learning to the prediction of vegetation health. Int. Arch. Photogramm. Remote Sens. Spatial Inf. Sci. XLI-B2, 465-469.

Cheng, C., Cheung, K., Chu, L. M. 2010. Thermal performance of a vegetated cladding system on facade walls. Building and Environment 45, 1779-1787.

Coops, N. C., Waring, R. H., Wulder, M. A., Pidgeon, A. M., \& Radeloff, V. C. 2009. Bird diversity: a predictable function of satellite-derived estimates of seasonal variation in canopy light absorbance across the United States. J. of Biogeography 36, 5, 905-918.

Colusca, S. E., Alpopi, C. 2011. The quality of Bucharest's green spaces. Theoretical and Empirical Researches. Urban Management 6, 4, 45-59.

Conway, D., Li, C., Wolch, J., Kahle, C., Jerrett, M. 2010. A spatial autocorrelation approach for exam- 
ining the effects of urban greenspace on residential property values? J. of Real Estate Finance and Economics 41, 2, 150-169.

Cohen, D. A., Marsh, T., Williamson, S., Golinelli, D., Thomas, L., McKenzie T.L. 2012. Impact and costeffectiveness of family Fitness Zones: A natural experiment in urban public parks. Health and Place $18,39-45$.

Craul, P. J. 1992. Urban Soils in Landscape Design. New York, John Wiley \& Sons, Inc., 385 pp.

Davis A. Y., Jung J., Pijanowski B.C., Minor E. S. 2016. Combined vegetation volume and "greeneess" affect urban air temperature. Applied Geography 71, 106-114.

Dogon-Yaro, M. A., Kumar, P., Abdul Rahman, A., Buyuksalih, G. 2016. Extraction of urban trees from integrated airborne based digital image and LiDAR point cloud datasets - initial results. Int. Arch. Photogramm. Remote Sens. Spatial Inf. Sci. XLII-2/W1, 81-88.

Dunnett, N., Kingsbury, N. 2004. Planting Green Roofs and Living Walls. Cambridge. Timber Press, Portland, $336 \mathrm{pp}$.

Ely, M., Pitman, S. 2013. Green infrastructure - Life support for human habitats. The compelling evidence for incorporating nature into urban environments. Botanic Gardens of Adelaide, 380 pp.

Fang, C., Ling, D. 2003. Investigation of the noise reduction provided by tree belts. Landscape and Urban Planning 63, 187-195.

Federer, C. M. 1976. Trees modify the urban microclimate. Journal of Arboriculture 2, 121-127.

Feltynowski, M. 2015. Spatial information systems a tool supporting good governance in spatial planning processes of green areas. J. of Urban \& Regional Analysis 7, 1, 69-82.

Holmgren, J., Persson, Å., Söderman, U. 2008. Species identification of individual trees by combining high resolution LiDAR data with multi-spectral images. Int. J. of Remote Sensing 29, 5, 1537-1552.

Hopkins, G., Goodwin, C. 2011. Living Architecture: green roofs and walls. Collingwood, VIC, CSIRO Publishing, $287 \mathrm{pp}$.

Hüse, B., Szabó, S., Deák, B., Tóthmérész, B. 2016. Mapping an ecological network of green habitat patches and their role in maintaining urban biodiversity in and around Debrecen city (Eastern Hungary). Land Use Policy 57, 574-581.

Ianos I., Merciu C., Merciu G., Zamfir D., Stoica V., Vlăsceanu Gh. 2014. Unclear perspectives for a specific intra-urban space: Vacaresti lake area (Bucharest city). Carpathian J. of Earth and Environmental Sci. 9,4, 215- 224.

Ianos I., Sorensen A., Merciu, C. 2017. Incoerence of urban planning policy in Bucharest: Its potential for land use conflict. Land Use Policy 60, 101-112.
Idilfitri, S., Sulaiman S., Salleh, N. S. 2014. Role of ornamental plants for bird community' habitats in urban parks, Procedia-Social and Behavioral Sciences, 153, 666-677, AMER International Conference on Quality of Life.

Jovanović, D., Govedarica, M., Sabo, F., Bugarinović, Ž., Novović, O., Beker, T., Lauter, M. 2015. Land cover change detection by using remote sensing a case study of Zlatibor (Serbia). Geographica Pannonica 19, 4, 162-173.

Kim, J., Muller, J.-P. 2011. Tree and building detection in dense urban environments using automated processing of IKONOS image and LiDAR data. $32,8,2245-2273$.

Lee, A. C. K., Jordan, H. C., Horsley, J. 2015. Value of urban green spaces in promoting healthy living and wellbeing: prospects for planning. Risk Manag Health Policy 8, 131-137.

Li, H., Liu, Y. 2016. Neighborhood socioeconomic disadvantage and urban public green spaces availability: a localized modeling approach to inform land use policy. Land Use Policy 57, 470-478.

Lima, R.F., Dallimer, M., Atkinson, F.P., Barlow, J. 2013. Biodiversity and land-use change: understanding the complex responses of an endemic-rich bird assemblage. Diversity Distrib. 19, 411-422.

Lull, H. W., Sopper, W. E. 1969. Hydrologic effects from urbanization on forested watersheds in the Northeast, U.S. Department of Agriculture, Forest Service, Research Paper NE-146.

Maas, J., Verheij, R. A., Groenewegen, P. P., de Vries, S., Spreeuwenberg, P. 2006. Green space, urbanity, and health: how strong is the relation?. Journal of Epidemiology and Community Health 60, 587-592.

McFarland, T.M., Mathewson, H.A., Groce, J.E., Morrison, M.L., Newnam, J., Snelgrove, R.T., Skow, K.L., Collier, B.A., Wilkins, R.,N. 2012. Utilization of a species occupancy model for management and conservation. Wildlife Society Bulletin 36, 3, 432-439.

Mészáros, M., Pavić, D., Trifunov, S., Srdanović, M., Seferović, S. 2014. Possibilities of applying CORONA archive satellite images in forest cover change detection - example of the Fruška Gora mountain. Geographica Pannonica 18, 4, 96-101.

Mihai, B. A. 2007. Remote sensing. Introduction to digital image processing. Vol. I. University of $\mathrm{Bu}-$ charest Publishing House, Bucharest, 208 pp.

Mihai, B. A. 2009. Remote sensing: concepts and principles. Vol. II. University of Bucharest Publishing House, Bucharest, 190 pp.

Mihai, B. A., Nistor, C., Săvulescu, I. 2013. Encyclopaedic dictionary of Remote Sensing, Photogrammetry elements and image analysis. Vol. 1 (A-Î). University of Bucharest Publishing House, Bucharest, $668 \mathrm{p}$. 
Milanović, M. M., Perović, V. S., Tomić, M., Lukić, T., Radovanović, M. M., Ninković, M. M., Samardžić, I., Miljković, Đ. 2016. Analysis of the state of vegetation in the municipality of Jagodina (Serbia) through remote sensing and suggestions for protection. Geographica Pannonica 20, 2, 70-78.

Millennium Ecosystem Assessment (2003). Ecosystems an human well-being: a framework for assessment. Island Press, Washington, DC.

Mitchell, B. A., Maher, B. A., Kinnersley, R. 2010. Rates of particulate pollution deposition onto leaf surfaces: temporal and inter-species magnetic analyses. Environmental Pollution 158, 1472-1478.

Mohamad, N. H., Idilfitri S., Thani, S. H. 2013. Biodiverity by design: the attributes of ornamental plants in urban forest parks. Proceedings of SEAN Conference on Environment-Behaviour Studies Procedia-Social and Behavioral Sciences, A 105, 823-839.

Morante-Filho, J. C., Faria D., Mariano-Neto E., Rhodes, J. 2015. Birds in anthropogenic landscapes the responses of ecological groups to forest loss in the Brazilian Atlantic Forest. PLoS One 10, 6, eo128923.

Näsi, R., Honkavaara, E., Tuominen, S., Saari, H., Pölönen I., Hakala, T., Viljanen, N., Soukkamäki, J., Näkki, I., Ojanen, H., Reinikainen, J. 2016. UAS based tree species identification using the NOVEL FPI based hyperspectral cameras in visible, NIR and SWIR spectral ranges. Int. Arch. Photogramm. Remote Sens. Spatial Inf. Sci. XLI-B1, 1143-1148.

Nita M. R. 2016. Green infrastructures - a geographical approach, Ethnological Press, Bucharest, 141 pp.

Nowak, D. J., Crane, D. E., Stevens, J. C. 2006. Air pollution removal by urban trees and shrubs in the United States. Urban Foresty \& Urban Greening 4, 115-123.

Ongoma, V., Muange, P. K., Shilenje, Z. W. 2016. Potential effects of urbanization on urban thermal confort, a case study of Nairobi city, Kenya: a review. Geographica Pannonica 20, 1, 19-31.

Ornithological Society in Romania/BirdLife International, Asociation for Birds Protection and Nature "Milvus Grroup”. 2015. Atlas of species of community interes in România. Water and Forests and Ministry, Biodiversity Directorate, Noi Media Print SA \& Media \&Nature Consulting SRL.

Papadopol, A., Petrescu, A. 1991. L'avifaune de la zone de la ville de Bucarest et de ses environs: aspects écologiques et évolution à travers les années. Trav. Mus. Nat. His. Nat. Gr. Antipa 31: 427-443.

Papadopol, A., Petrescu, A. 2006. Contributions to the knowledge of food, of relationship and trophic groups in some species of birds in Romania. Oltenia Museum Craiova. Studies and communications. Nature Sciences 22, 248-257.
Petrisor, A. I. 2015. Assessment of the green infrastructure of Bucharest using CORINE and Urban Atlas data. Urbanism, Architecture, Constructions 6, 2, 19-24.

Rayner, J. P., Raynor, K. J., Williams, N.S.G. 2010. Façade Greening: a Case Study from Melbourne, Australia. Acta Horticulturae 881, 709-714.

Rosenfeld, A. H., Akbari, H., Romm, J.J., Pomerantz, M. 1998. Cool communities: strategies for heat island mitigation and smog reduction. Energy and Buildings 28, 1, 51-62.

Rouse, D.C., Bunster-Ossa, I.F. 2013. Green Infrastructure: A Landscape Approach. American Planning Association. Planning Advisory Service Report Number 571.

Scaunas, S., Merciu, G. 2016. Using the LiDAR in analyzing the relationship between vegetation and built space - influences and interdependence. Case study: Bucharest Municipality. GeoPatterns 2, 1, 6-12.

Sirodoev, I., Cheval, S., Dumitrescu, A., Merciu, C., Vaidianu, N., Paraschiv, A., Schvab, A., Saghin, A., Prefac, Z. 2015. Contribution of the built-up space to the creation of urban heat island in Bucharest Municipality. J. of Environ. Protection and Ecology, 16, 4, 1337-1343.

Van Renterghem, T., Bottledooren, D., Verheyen, K. 2012. Road traffic noise shielding by vegetation belts of limited depth. J. of Sound and Vibration 331, 2404-2425.

Wolch, J. R., Byrne J., Newell, J. P. 2014. Urban green space, public health, and environmental justice: the challenge of making cities 'just green enough', Landscape and Urban Planning 125, 234-344.

Xiao, Q., McPherson, E. G., Simpson, J. R., Ustin, S. L. 2006. Hydrologic processes at the urban residential scale. Hydrological Processes 21,16, 2174 - 2188.

$$
\propto
$$

Directive 2009/147/EC of the European Parliament and of the Council of 30 November 2009 on the conservation of wild birds, with annexes - DP.

Government Emergency Ordinance no. 57/2007 on the status of protected natural areas, conservation of natural habitats, flora and wild fauna, with annexes.

Red Book of Vertebrates of Romania, The Romanian Academy, 2005 - LR RO.

Law 407/2006 of hunter and hunting Fund protection adopt, with annexes - LV.

The IUCN Red List of Threatened Species - LR IUCN cat. 2012: LC - Least concern, NT-Near threatened, VU - Vulnerable, EN - Endangered, CR - Critically endangered. 
Convention on the Conservation of European Wildlife and Natural Habitats or "Bern Convention" (Bern, 19 September 1979).

Convention on the Conservation of Migratory Species of Wild Animals or "Bonn Convention" (Bonn, 23 June 1979.

Agreement on the Conservation of African-Eurasian Migratory Waterbirds (Romania adhered by Law no. 89 of 10 May 200o).
Convention on International Trade in Endangered Species of Wild Fauna and Flora (Romania adhered by Law no.69 of 15 July 1994) - CITES.

\section{Other sources}

Internet 1: http://landsat.usgs.gov/band_designations_landsat_satellites.php (12.02.2016.). 